\title{
堆積盆地における地震波コーダの性質
}

\author{
京都大学理学部地球物理学教室 出 射 隆 文 - 堀 家 正 則 \\ 京都大学防㷋研究所岩田知孝 \\ (昭和 60 年 4 月 5 日受理)
}

\section{Seismic Coda Waves Observed on a Sedimentary Basin}

\author{
Takafumi IDEI and Masanori HoRIKE \\ Geophysical Institute, Faculty of Science, Kyoto University \\ Tomotaka IwATA \\ Disaster Prevention Research Institute, Kyoto University
}

(Received April 5, 1985)

\begin{abstract}
We have investigated the characteristics of $S$ coda waves on a sedimentary basin for examining if they may be applicable to estimate the stable amplification factor. The results are as follows: (1) R.M.S. amplitude ratios of coda waves observed on the basin to coda waves on the nearest rock site were inconsistednt with the ratios of $S$ waves between the above two sites for frequecies lower than $3 \mathrm{~Hz}$. The ratios of coda waves scattered as much as those of $\mathrm{S}$ waves. (2) The phase velocities determined for coda waves on the basin were consistent with those of Rayleigh waves estimated by another study. (3) Comparing coda waves observed on the basin with those synthesized through convolving the $\mathrm{SH}$ wave response for the basin and the seismogram on the rock site, the former was much smaller than the latter. From the above three results, coda waves on the basin seem to consist of not only single-scattering $\mathrm{S}$ waves but also surface waves generated locally. It is therefore difficult to estimate reliable amplification factor from coda waves observed on the sedimentary basin.
\end{abstract}

\section{§1. はじめに}

ある地域の地震動予測を行なう際に, 震源, 伝搬経路, その地域の地下構造の 3 つの要因を 考慮しなければならない。震源距離，規模の同じ地震でも，伝搬経路の $Q$ 值及び観測点近傍 の地下構造によつて地震動の強さは大きく異なる. 例えば最近では, 東北地方の太平洋側と日 本海側における地震波の距離減衰の違いが，上部マントルの $Q$ 值の違いによつて説明されて おり [HASEGAWA et al. (1978)]，また観測点近傍の影響については，堆積層による増幅効果 [IRIKURA and AKAMATSU (1974)]，あるいは不規則境界による効果 [IWATA and IRIKURA (1984)] などが報告されている，以上の事から，地震動を予測する上で，地域的な距離減衰特 性及び観測点近傍の地下構造を正確に求めることの重要性が明らかとなる.

ところで， $Q$ 值及び地盤の増幅特性は， 2 点間のスペクトル比を介して求めるのが普通であ る.しかし，ノイズの含まれたスペクトル比は統計学的に不安定であるため [JENKINS and 
WATTS (1960)] この方法で得られる增幅特性は極めて大きなばらつきを示すことがあり [IRIKURA and AKA MATSU (1974)], Q 值にいたつては, しばしば負の值が得られる事さ兄 あり，何らかの他の方法でこの問題点を解決することが望まれる.

AKI (1969) は, 近地地蜄のコーダは, ランダムに分布する不均質からの後方散乱波であり, そのパワースペクトルの減衰曲線は, 地震規模, Radiation Pattern, 観測点及び震源位置に依 存せず，発震時からの経過時間のみに依存することを示した，その後，コーダのこのような性 質に注目して, 震源や媒質の特性の研究が様々な地域で行なわれるよらになつた [RAUTIAN and Khalturin (1978); Singh and Herrmann (1983); Tsujiura (1978); etc.]. また, $1 \sim 25 \mathrm{~Hz}$ の $\mathrm{S}$ コーダの弾性波としての本性については, その $Q$ 值と $\mathrm{S}$ 波の $Q$ 值が一致す ること [AKI (1981)] と，異なる岩盤上で観測された S 波の振幅比とコーダの振幅比が一致 すること [TSUJIURA (1978)] から主に S 波の後方散乱波であると考兄られるうになつてき ている.

更に TSUJIURA (1978) は，S コーダの比のほうが S 波の比よりはるかに安定しているこ

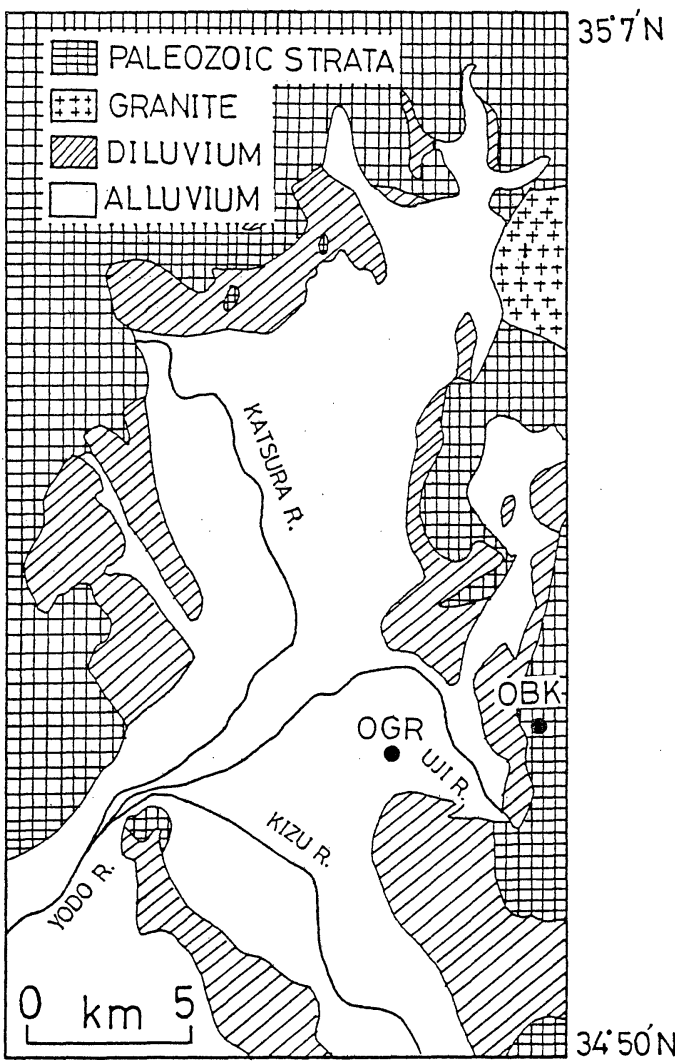

$135^{\circ} 40^{\prime} \mathrm{E}$

Fig. 1. Geological map of the Kyoto basin. The symbols OGR and OBK denote the observation sites.

とを示した。この様なコーダの性質は， 自然に以下の可能性に導く。すなわち,

もし地盤におけるコーダも岩盤上と同様 にS 波の後方散乱波であると仮定できる ならば，岩盤上のコーダとの比を求める ことにより，S 波主要動の比を用いる場 合よりはるかに精度よく， S 波に対する 地盤の増幅特性及び $Q$ 値を推定できる 可能性が考兄られる.

本研究では，地盤上で観測されたコー ダを調べ，上に述べた可能性を検討する ことにする．第 1 に，地盤及び岩盤上で 観測されるコーダのスペクトル比が， S 波主要動の比と比較して安定かどうかを 調べてみる。しかし，未固結の堆積層が 存在する場合には，表面波の様に地表面 近くにトラップされる波が二次的に強く 励起される可能性がある. 実際, 地盤上 での地震波は岩盤上に比べて複雑であり， 特にコーダの部分は様々な波の重ね合わ せである可能性があり，その場合，岩盤 上と同じょらに，主にS 波の後方散乱波 であるとみなせないかもしれない、そこ で第 2 に，地盤上でのコーダの波の本性 を調べてみる。この目的のために次の 2 つの方法を用いる. 1 つは，地盤上での 
三点観測の記録からコーダの波の到来方向及び位相速度を求め，波の種類を推定する方法であ る.むう 1 つは，別の研究で推定されている基盤から地表までの速度構造に，岩盤での記録を 基盤からの入射波と仮定して与光，地盤の応答をもとめて地盤上での観測記録と比較してみる 方法である。

\section{§2. 観測及び記録}

\section{1. 観測場所及び観測方法}

地盤上の観測点として京都盆地南部の巨椋池干拓地 (OGR), 岩盤上の 観測点としてそこか ら東方約 $5 \mathrm{~km}$ 離れた山腹の古生層岩盤露頭上 (OBK) を選んだ (Fig. 1). OGR, OBK を

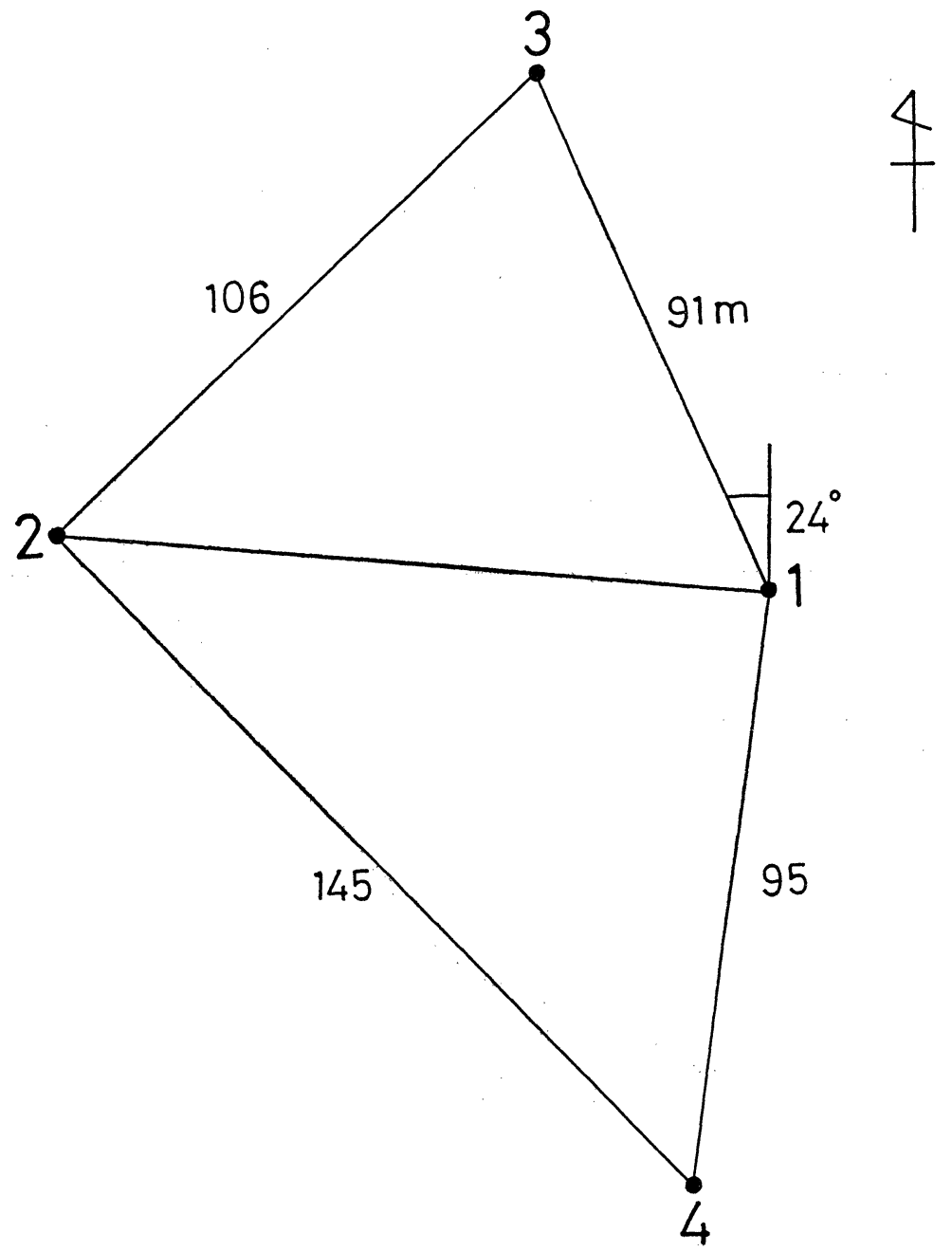

Fig. 2. Configuration of the two types of tripatite array at OGR. Sites $1,2,3$ constitute type I array and Sites 1, 2, 4 type II array. Site 4 removed from Site 3 on June 2, 1985. 
含む京都盆地南部全体の基盤構造は，狐崎・他（1971）によつて推定されており，OGR 付近 の基盤までの堆積層の厚さは約 $700 \mathrm{~m}$ である.これとは別に, OGR の堆積層の地下構造は, 川部・他 (1984) により浅層反射法によつて，また，HORIKE (1985) により微動を用いたイ ンバージョンによつて，それぞれ推定されている.これらの結果から OGR 近傍の地盤は，水 平成層構造で近似できる事がわかる，地質的には，盆地周辺の山は，ほとんぞ古生層の岩から なり，盆地内はせいぜい厚さ数十丣の薄い沖積層の下に厚い洪積層が古生層の基盤まで堆積し ていると考えられている[狐崎・他 (1971)].

OGR での三点観測は, Fig. 2 のように Types I, II の 2 種類行なつた. Type II の Site 4 は, 1984 年 6 月 2 日以降, Type I の Site 3 を移設したものであり,この点は他の 3 点 よりも $1 \mathrm{~m}$ 位高い学校敷地内に設けられた.

また，観測には OBK においては固有周期 2 秒，OGR においては固有周期が上下動は 1 秒, 水平動は 2 秒の速度型地震計をもらいた。

\section{2. 記録}

今回の解析に用いた地震を Table 1 に示す。 また，その震源位置を Fig. 3 に示す。震央 距離は $10 \sim 100 \mathrm{~km}$ で, マグニチュードは $2.7 \sim 4.3$ の範囲であり, 特に 1984 年 5 月 30 日 の山崎断層での地震 ( $M$ 5.6) の余震が多い.

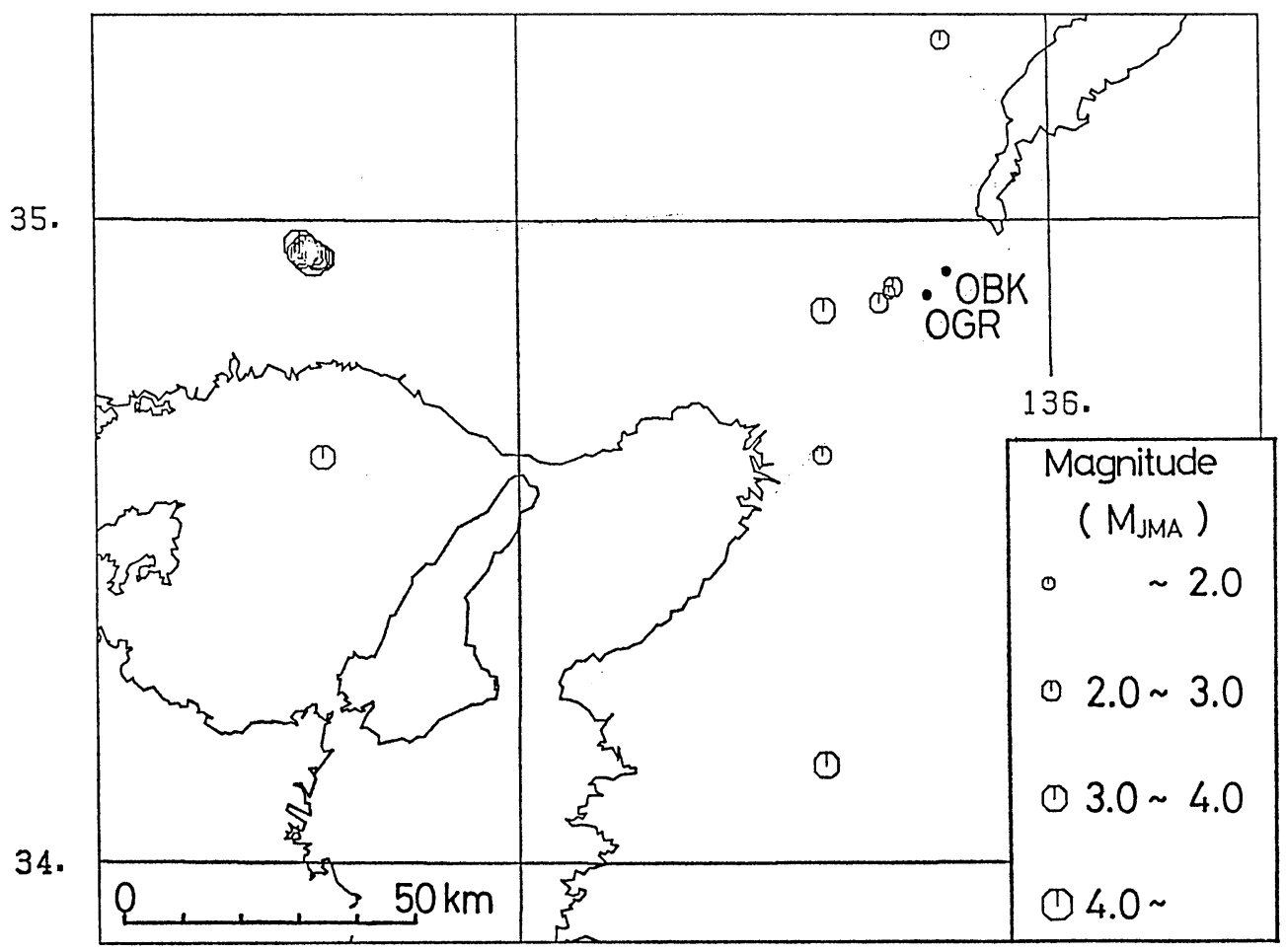

135.

Fig. 3. Epicenters of earthquakes analysed in the present study. 
Table 1. List of events recorded at OGR and OBK.

\begin{tabular}{|c|c|c|c|c|c|c|c|c|}
\hline No. & YEAR & $M D$ & H M & SEC. & Lat. & Long. & $\underset{(\mathrm{km})}{\text { Depth }}$ & $M(J M A)$ \\
\hline 1 & 1984 & 519 & $16: 39$ & 29.44 & 3452.4 & 13540.7 & 9 & 2.7 \\
\hline 2 & & 524 & $4: 00$ & 1.99 & 3453.3 & $\begin{array}{ll}135 & 41.8\end{array}$ & 11 & -- \\
\hline 3 & & 527 & $15: 29$ & 49.16 & 3453.8 & 13542.3 & 15 & 3.0 \\
\hline 4 & & 530 & $10: 20$ & 58.82 & 3456.5 & 13437.5 & 17 & 3.8 \\
\hline 5 & & & $10: 30$ & 58.41 & 3456.2 & 13436.9 & 17 & 4.1 \\
\hline 6 & & & $11: 06$ & 17.08 & 3457.0 & 13436.1 & 16 & 3.9 \\
\hline 7 & & & $11: 16$ & 6.25 & 3456.5 & 13437.8 & 15 & 3.8 \\
\hline 8 & & & $11: 31$ & 36.91 & 3456.4 & 13438.0 & 16 & 3.3 \\
\hline 9 & & & $12: 36$ & 1.05 & $34 \quad 56.9$ & 13437.0 & 16 & 3.4 \\
\hline 10 & & & $20: 43$ & 55.00 & 3438.0 & 13438.0 & 16 & 4.0 \\
\hline 11 & & & $22: 31$ & 49.93 & 3457.0 & 13436.2 & 15 & 4.0 \\
\hline 12 & & 531 & $2: 08$ & 13.27 & $34 \quad 9.1$ & 13534.2 & 73 & 3.9 \\
\hline 13 & & & $8: 28$ & 20.90 & 3456.6 & 13437.5 & 17 & 3.4 \\
\hline 14 & & 61 & $5: 29$ & 53.22 & 3456.9 & $134 \quad 35.4$ & 17 & 3.6 \\
\hline 15 & & & $8: 41$ & 28.86 & 3457.5 & 13436.1 & 15 & 3.4 \\
\hline 16 & & 62 & $16: 12$ & 36.43 & 3457.7 & $134 \quad 35.4$ & 18 & 4.3 \\
\hline 17 & & 63 & $21: 27$ & 15.30 & 3456.3 & 13435.7 & 15 & 3.0 \\
\hline 18 & & 65 & $13: 47$ & 51.46 & 3456.9 & 13435.8 & 16 & 4.0 \\
\hline 19 & & 712 & $0: 04$ & 42.38 & $\begin{array}{ll}35 & 16.8\end{array}$ & 13548.0 & 13 & 2.9 \\
\hline 20 & & 714 & $22: 28$ & 49.51 & 3438.2 & 13534.1 & 13 & 2.8 \\
\hline 21 & & 717 & $1: 49$ & 16.77 & 3451.7 & 13534.4 & 14 & 3.6 \\
\hline 22 & & 89 & $6: 47$ & 53.06 & $\begin{array}{ll}35 & 9.7\end{array}$ & 13643.3 & 15 & 3.8 \\
\hline 23 & & 819 & 5:03 & 23.26 & $\begin{array}{ll}34 & 52.8\end{array}$ & 13540.4 & 14 & 3.0 \\
\hline
\end{tabular}

\section{§3. 解析及び結果}

\section{1. $\mathrm{S}$ 波及び $\mathrm{S}$ コーダによって推定された地盤の增幅特性の比較}

\section{(1) 解析方法}

OGR, OBK の NS, EW 成分の記録を 5 段階のバンドパス・フイルター (中央周波数, $0.75,1.5,3.0,6.0,12.0 \mathrm{~Hz}$ ，バンド幅，0.5，1.0，2.0，4.0，8.0 Hz） に通す。その結果を Fig. 4 に示す. ついで, 0.1 秒おきに 10 秒間のウインドウをかけ, RMS 振幅を求める.こ こで，時間 $t$ における RMS 振幅 $A_{\mathrm{rms}}(t)$ は，次式で定義することにする.

$$
A_{\mathrm{rms}}(t)=\frac{1}{w} \cdot \sqrt{\sum_{u=t-w / 2}^{t+w / 2} A^{2}(u)}
$$

ここで $w$ はウインドウの長さである.

ウインドウの長さについては 5 秒と 10 秒を試行した結果, 5 秒ぐらいでは短すぎ, RMS 振幅が時間とともにがたついて、コーダの滑らかな減衰が表わせず，10 秒に決定した。こう して求められた RMS 振幅を用いて, OGR と OBK との振幅比を求める. S 波に関しては, $\mathrm{S}$ 波主要動の始まりから 10 秒間振幅の RMS 比を求め, またコーダに関しては, 起震時か らの経過時間で波の到着時間の 2 倍の所を始まりとし [RAUTIAN and KHALTURIN (1978)], $\mathrm{RMS}$ 振幅で $\mathrm{S} / \mathrm{N}$ が 3 の所で終わりと定義し, その間で起震時からの経過時間が 50 秒の所 での RMS 振幅の比を求める. 比を求める時間を 50 秒にした理由は, 解析した地震はニーダ が 40 秒あたりに始まるものが多く, あまり後方では $\mathrm{S} / \mathrm{N}$ が十分高い地震の数が少なくなり 
すぎるためである.

また，地盤における 3 つ観測点の場所による影響が上の解析結果に影響していないかどう かを調べるため, Site 1 に対する Sites $2,3,4$ のコーダの比も求めてみる.

(2) 結 果

No. 1 23 の地震の NS 及び EW 成分についての S 波及びューダの比を Fig. 5 に示す. 各周波数毎に地震の個数が異なるのは, 経過時間が 50 秒の所で $\mathrm{S} / \mathrm{N}$ が 3 以上の場合にのみ プロットしてあり，高周波へいくほど $\mathrm{S} / \mathrm{N}$ が悪くなり (Fig. 4), $\mathrm{S} / \mathrm{N}$ が 3 以上の地震が少 なくなつているためである.実線は各周波数毎の平均值を結んだものである.Fig. 5 による と, $\mathrm{S}$ 波, コーダともに $6 \mathrm{~Hz}$ にピークが見られ, また, 比の值もよく一致している. しかし, $3 \mathrm{~Hz}$ 以下の低周波については, 比の傾向はよく似ているが, その值はコーダの比の方が 2 倍 程度大きく見積られている. $12 \mathrm{~Hz}$ については，NS 成分では S 波及びューダの比が一致し ているが， EW 成分では $\mathrm{S}$ 波の方が大きくなつている. しかし $\mathrm{EW}$ 成分のコーダの比は 1 点しか求まつて抢らず，上記の傾向が系統的なものかどうか断定は出来ない，上の結果から， $6 \mathrm{~Hz}$ 以上の高周波についてはューダの比は地盤の増幅特性を示しているのに対して, $3 \mathrm{~Hz}$ 以 下の低周波については增幅特性を表わしていないものと考えられる.つまり, $3 \mathrm{~Hz}$ 迄の周波 数のコーダには, $\mathrm{S}$ 波以外の他の種類の波が含まれている可能性がある.一方, 比のばらつき は，S 波とコーダとでほとんど変わらず，TSUJIURA (1978) の結果とは一致しない.ゆえに， コーダの比を用いれば地盤の増幅特性がより精度よく推定できるかもしれないという予想は否

\section{NO.12 NS-Comp.}
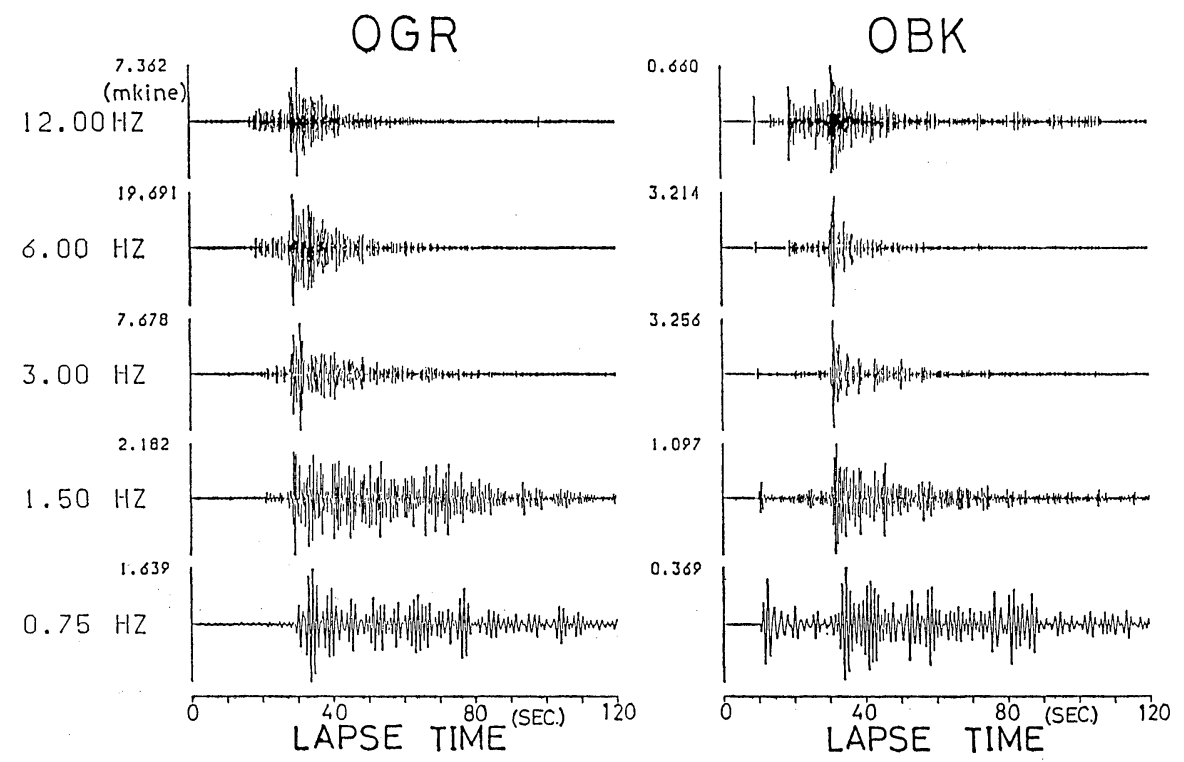

Fig. 4. An example of the filtered seismograms obtained at OGR and OBK. Center frequency of each filter is shown at the left side of the figure. The numbers at the left of each trace indicate maximum velocity amplitudes. 
定されなければならない。

次に, 経過時間 50 秒での Site 1 に対する Sites 2, 3, 4 のコーダの比を Fig. 6 に示す. これによると, Site 2/Site 1 は NS, EW 成分ともに, すべての周波数について, ほぼ 1 で あり, Site 3/Site 1 も, 比の傾向は少しばらつきはあるものの, 注ぼ 1 である. 一方, Site 4/Site 1 については此の傾向が变わり, $3 \mathrm{~Hz}$ で少し大きくなり，6,12 Hz と高周波になるに つれて減少している.このことは Site 4 で観測された波形を見てもわかり，明かに Sites 1 , 2 と比較して高周波成分が落ちている.これは, Site 4 が学校敷地内にあるためにその影響 が出たものと思われる.このことは，地震動が観測点のごく近傍の地下構造の影響を受けてい る可能性を示しており, 観測及び解析においては十分な注意が必要である. しかし, 今回の解 析では Type II での OGR の記録は Site 1 のものを用いたので，結果に対する影響はな い.

\section{OGR/OBK}

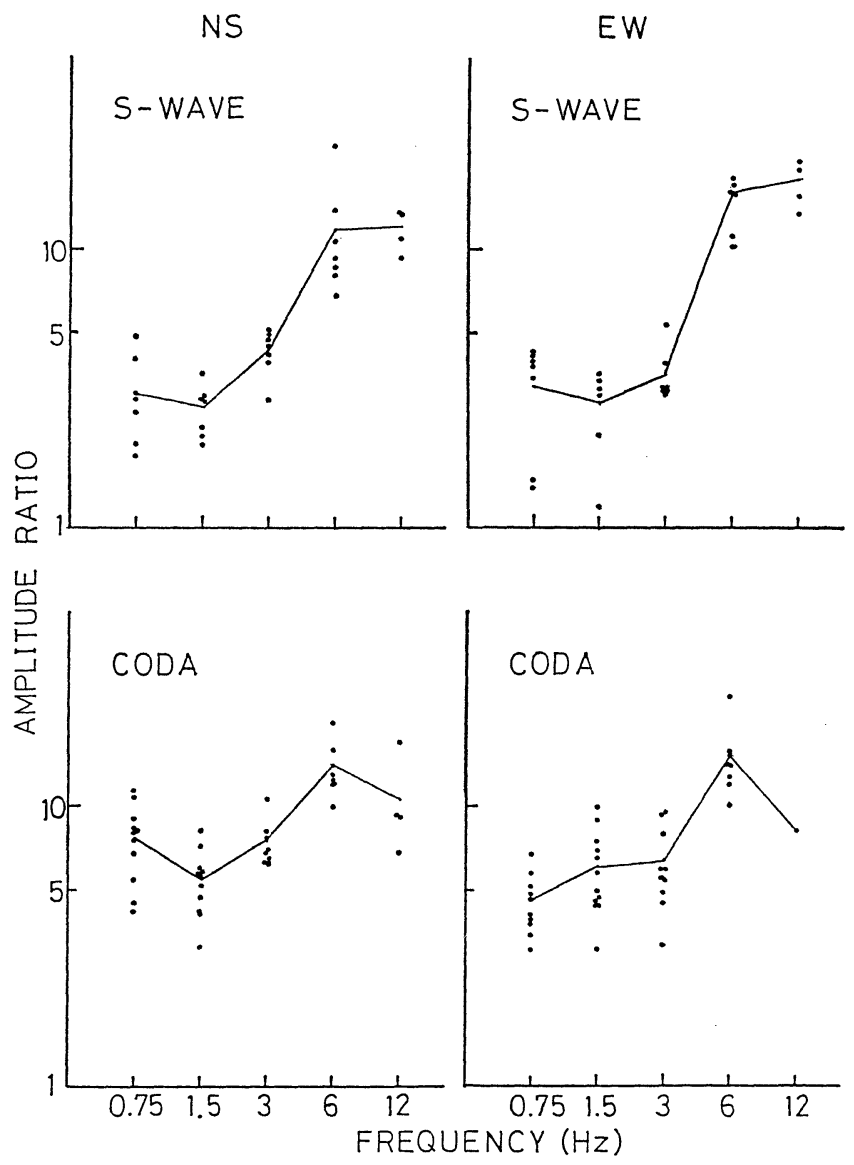

Fig. 5. Amplitude ratios of OGR to OBK for $S$ and $S$ coda waves, in the frequency range from 0.75 to $12 \mathrm{~Hz}$. Left and right diagrams show NS and EW components, respectively. Lines represent the average amplitude ratios for each frequency. 


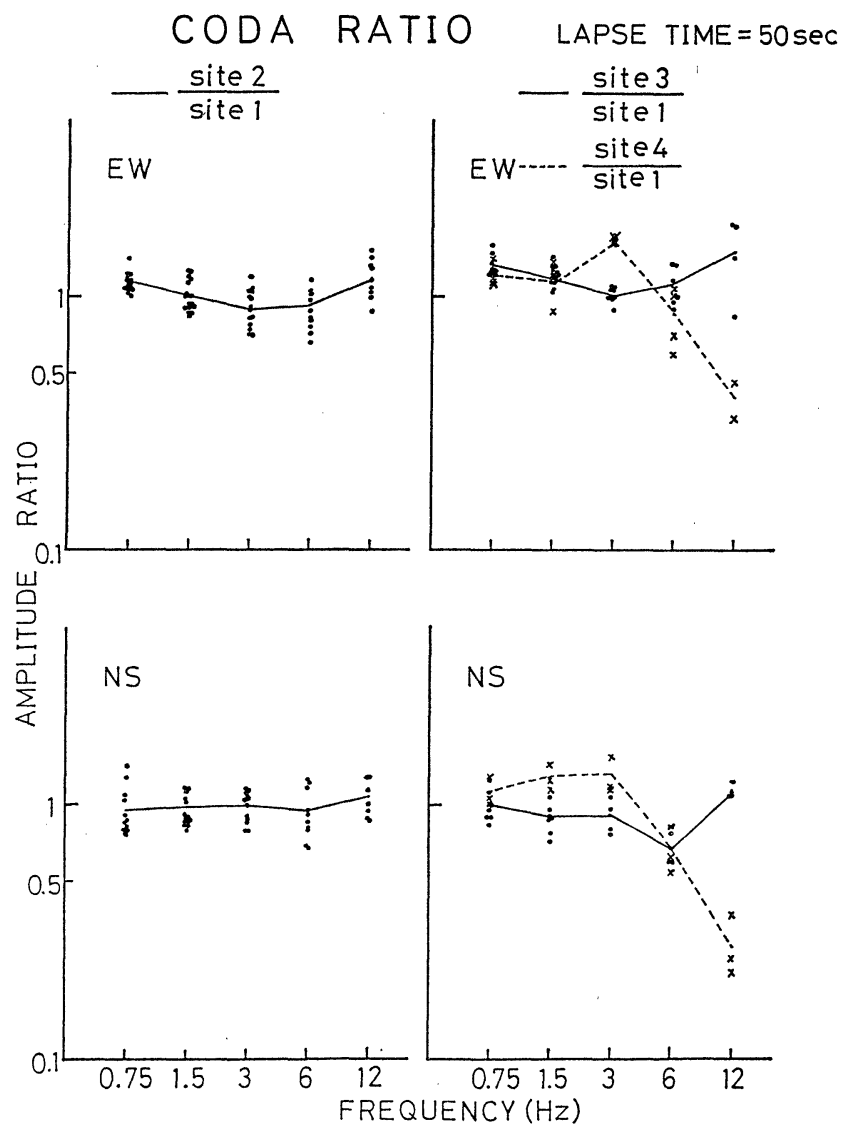

Fig. 6. Coda amplitude ratios of Sites 2,3 and 4 to Site 1 of the tripatite array at OGR. Top and bottom diagrams correspond to EW and NS components, respectively. In the right two figures, heavy and dashed lines represent coda amplitude ratios between Sites 3 and 1, and between Sites 4 and 1, respectively.

\section{2. $\mathrm{S}$ コーダの到来方向及び位相速度の推定}

\subsection{1. 位相差による推定}

\section{(1) 解析方法}

OGR に括ける 3 点の鉛直成分の記録を狭帯域のガウス関数型のバンドパス・フィルター [DZIEWONSKI et al. (1969)] に通し, 対応する波束について各点 2 間のいくつかのピークの時 間差を読み取る。この時間差は各地震計の位相特性を含んでいるので, 3 点の地震計のステッ プ応答から推定した位相差を各周波数に対して時間差に直し，この值だけ前記の時間差にさら に補正を加える．得られた結果から，各ピークの時間差が良く合つているものだけを選び，そ の平均值から波束の到来方向及び位相速度を推定する.

この解析に执いて, ステップ応答から求められたチャンネル毎の位相誤差は最大 $2^{\circ}$ 程度で あつたが, 観測状態の日々の恋化などを考慮すると, 位相差が $10^{\circ}$ 以下の波については速度 の分解能が不十分と思われる. この基準によると, $100 \mathrm{~m}$ の距離間で速度の分解能が十分ある 

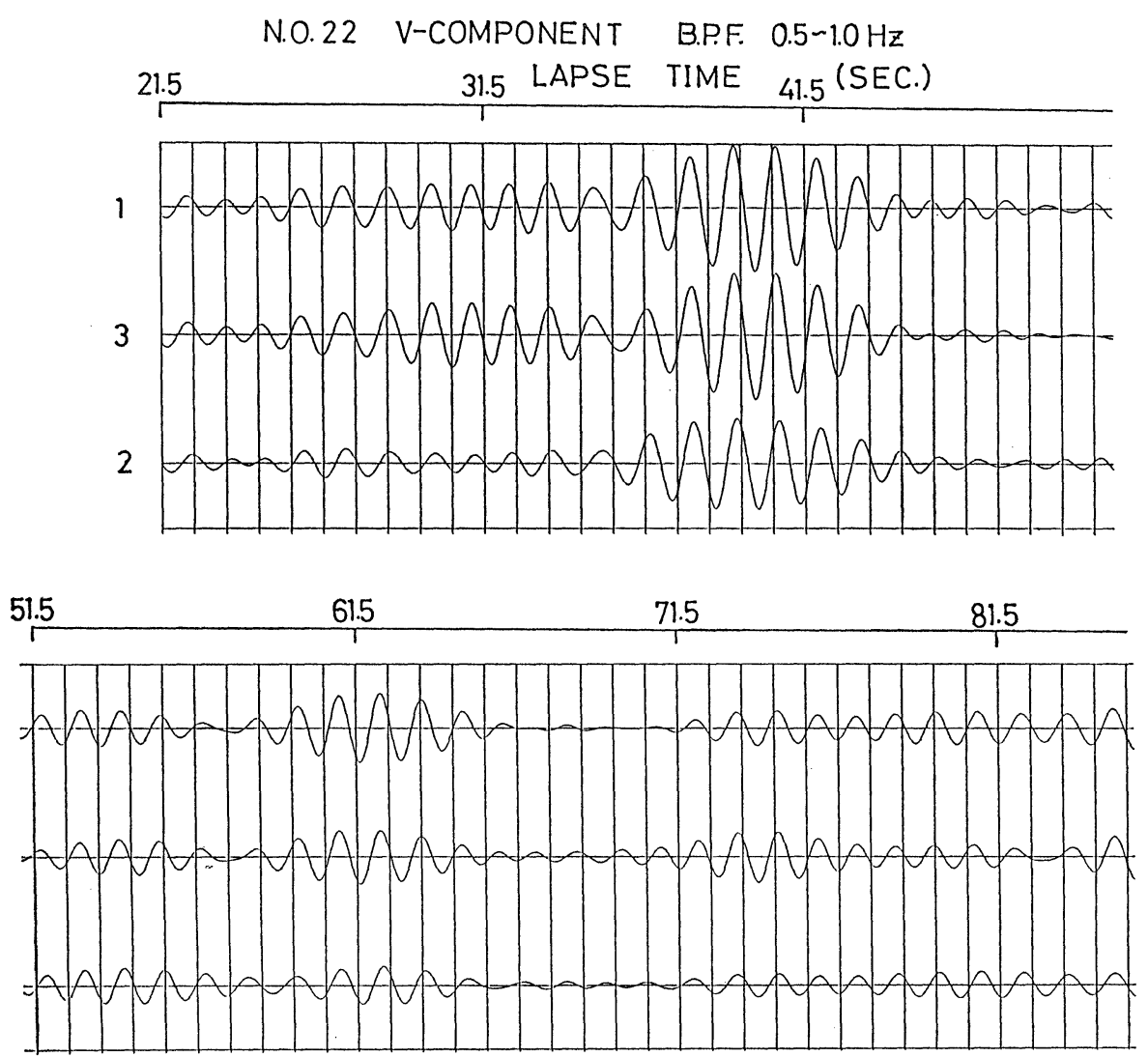

Fig. 7. Filtered seismograms $(0.5-1.0 \mathrm{~Hz})$ of three vertical components at OGR. The numbers at the left of each trace indicate observation point in Fig. 2.

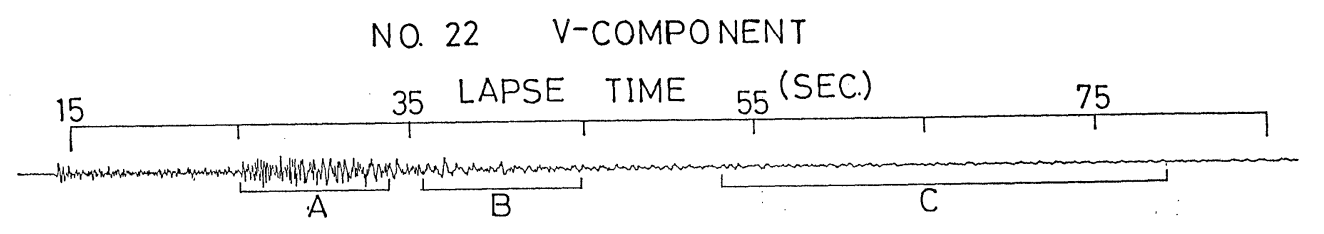

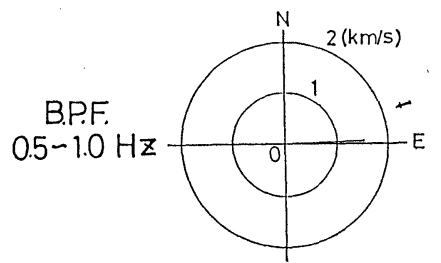

A

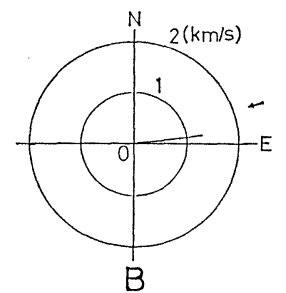

B

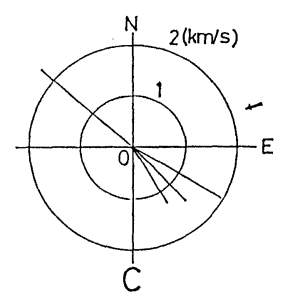

Fig. 8. An example of propagating direction and phase velocity. Arrows show the dirction of epicenter. 
のは, $0.5 \mathrm{~Hz}$ の波では $1800 \mathrm{~m} / \mathrm{s}$ 以下である. より高周波については, 周波数に比例してよ り速い速度まで分解能がある.

\section{(2) 結 果}

一例として No. 22 の地震について結果を示す. Fig. 7 は, $0.5 \sim 1.0 \mathrm{~Hz}$ のバンドパス・フ ィルターに通した結果で，コーダの部分をで各観測点間で波束の対応の良いことが分かる，そ れから得られた波の到来方向及び位相速度を Fig. 8 に示す. Fig. 8 において矢印は震源方 向を示し, 線の向きは到来方向を, 長さは速度を表わしている. それによると, S 波の到着時 間から 9 秒間 (Fig. 8 の A) が 1 つの波束に対応し，震源方向からの波であると考えられる. また，11 秒後から 9 秒間 (B) も震源方向からの波であり，その速度（約 $1.3 \mathrm{~km} / \mathrm{s}$ ) から表 面波であると考えられる. しかし，コーダにあたる時間が 52 秒から 79 秒 (C) に対応する 4 つの波束は, その波の方向が震源方向と無関係であり, その速度も $1.2 \sim 2.3 \mathrm{~km} / \mathrm{s}$ とまちま ちである. 従つて, この部分の波は震源からのものではなく, 二次的に発生したものと考えら れる.

同様にして, 他の地震についても解析を行つた. しかし，すべての波束について上の例のよ らに速度が求まる訳でなく，多くの波の重なり合つたものや，分解能を超えた速い速度のもの は除かれている. 結局, 速度が求められた波束は全体の 5 割程度であつた。 また, $1.5 \mathrm{~Hz}$ 以 上の高周波になると，3 点間の波束の対応が悪くなり，この方法では速度の推定できなくなつ

NO. $6 \quad V$-Comp. Lapse-time 40-100 sec
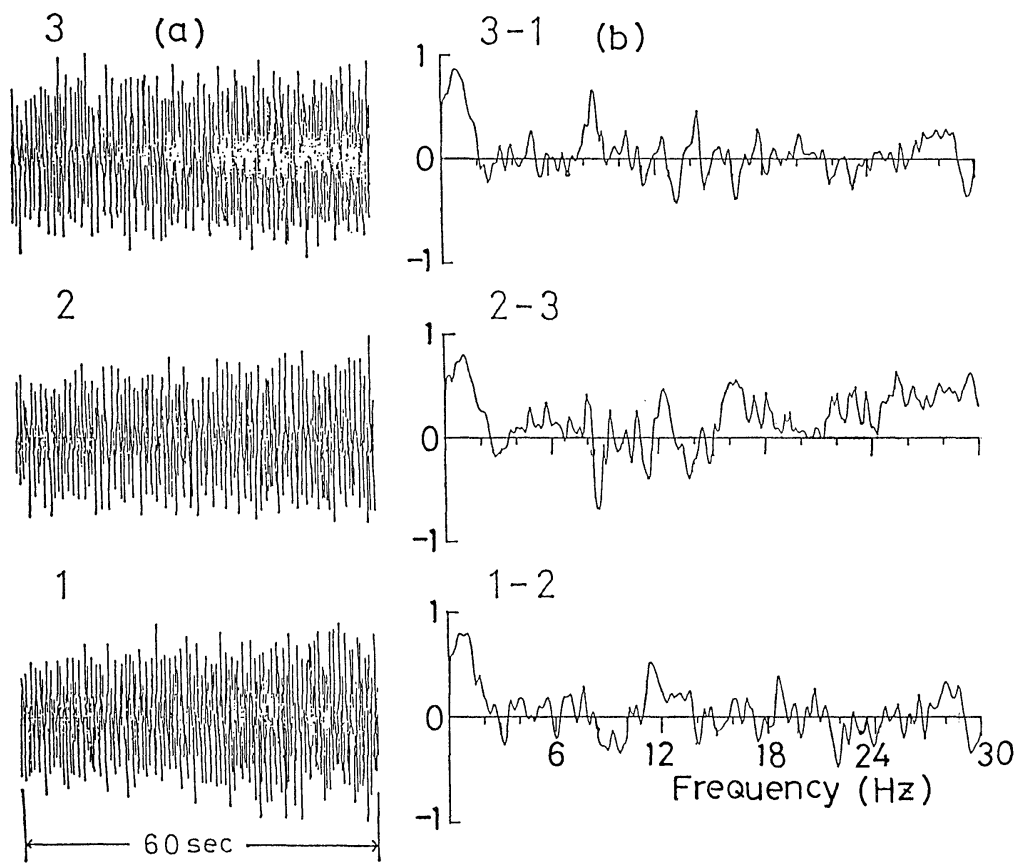

Fig. 9. (a) Stationarized seismograms of coda parts. (b) Spatial autocorrelation coefficients of each two points. The numbers in front of the traces denote the observation points in Fig. 2. 
た。そこで，より高周波については次の方法を用いることにした．

\subsection{2. 空間自己相関係数による推定}

\section{(1) 解析方法}

AKI (1957) により考案された空間自己相関係数よる方法で速度を求めてみる.ここでは, コーダが各周波数に対して単一速度を持つ波が等方的に到来していると仮定する．その時， 2 地点間の上下動の空間自己相関係数は,

$$
\rho(r, \omega)=J_{0}(\omega \cdot r / c(\omega))
$$

と表わされる.ここで, $\rho(r, \omega)$ は, 2 点間の距離 $r$, 角周波数 $\omega$ での相関係数で, $c(\omega)$ は周 波数 $\omega$ の波の速度である.

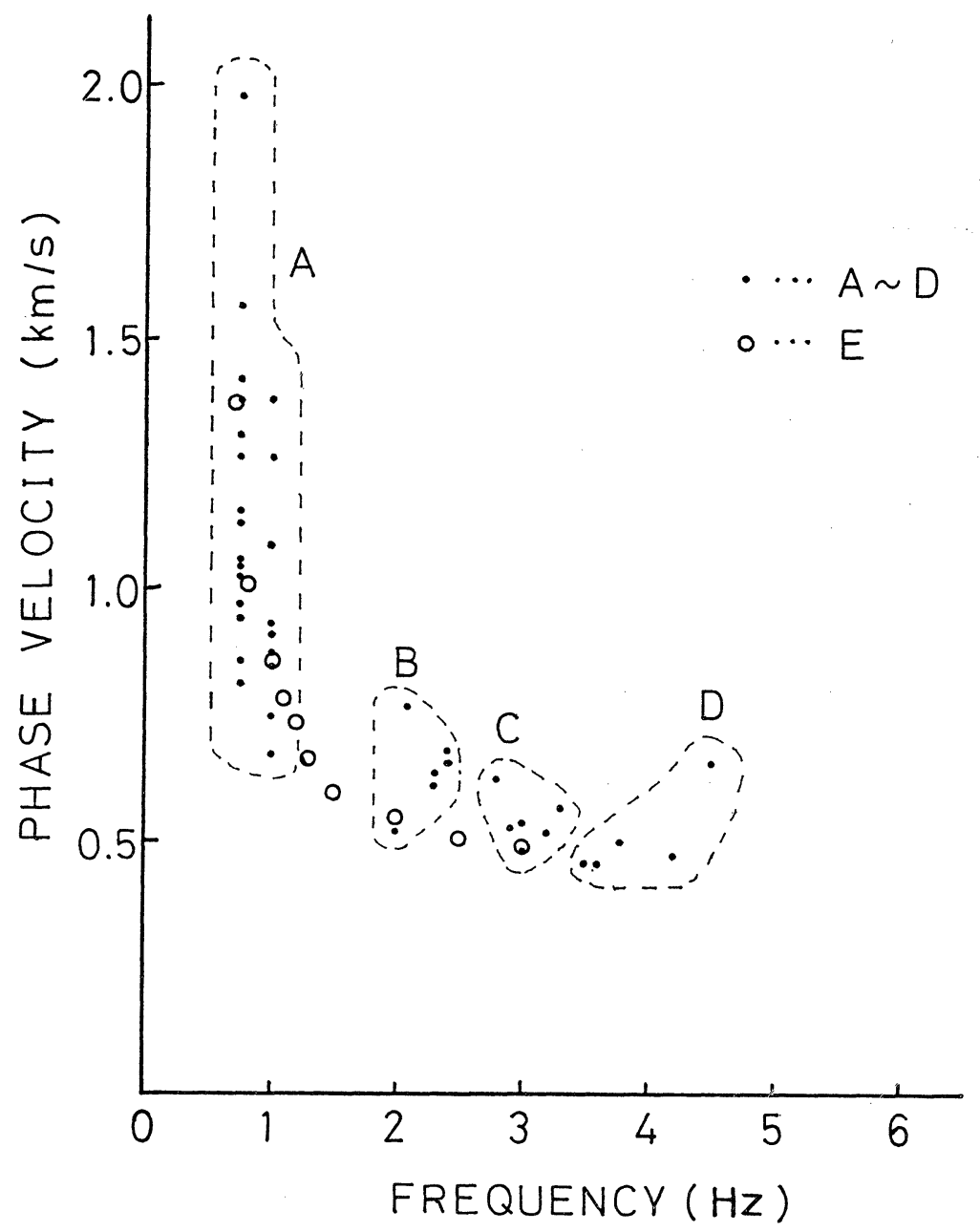

Fig. 10. Phase velocities estimated for coda waves at OGR, A: by time-lag of peaks in filtered data, B-D: by spatial autocorrelation coefficients, B: from first zero, C: from first minimum, and $\mathrm{D}$ : from second zero. $\mathrm{E}$ shows phase velocities of Rayleigh waves at OGR obtained by HoRIKE (1985). 
この方法では 2 地点における時系列は定常的でなければならない。そこで解析においては, コーダの始をりから 60 秒間の記録の後の方を増幅して, 定常の仮定を満たすようにし，その 記録について 2 点間の相互相関係数を求め, そのフーリエスペクトルの実部をとることによつ て相関係数を求めるようにした.

このようにして記録から求められた相関係数が (1) 式で近似できるものとして解析する. 実際には相関係数とベッセル関数 $J_{0}(x)$ の零点, 極大值, 極小值を対応させて, $c(\omega)$ を求める.

\section{(2) 結 果}

No. 6 の地震についての結果を示す. Fig. 9(a) が定常化された記録であり，(b) はその空 間自己相関係数である.これによると, ベッセル関数で近似できるのは最初の零点, 極小值, 2 番目の零点むでで，それょり高周波についてはベッセル関数で近似する事ができず，速度を 求める事が出来なかつた。

他の地震についても同様の解析を行つたが, 解析したすべての地震について, その空間自己 相関係数がベッセル関数で近似できるわけでなく, 近似できた地震について速度は $2.0 \sim 5.0 \mathrm{~Hz}$ で $700 \sim 400 \mathrm{~m} / \mathrm{s}$ と求められた.

\subsection{3. 結 果}

上の 2 つの解析方法によつて得られた位相速度を Fig. 10 に示す.これによると, 今回の 解析で求められた位相速度は, HoRIKE (1985) によつて得られたレーリー波の位相速度とよく 一致する.したがつて，この結果はコーダには表面波が含まれていることを示していると考え られる.

\section{3. 地盤の応答}

\section{(1) 計算方法}

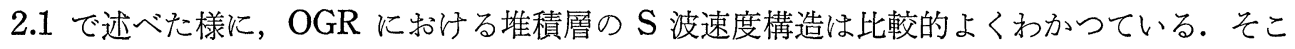
で，岩盤上で観測されたコーダを堆積層下面に入力として与えたその構造に対する $\mathrm{S}$ 波応答 を合成し, 地盤上で実際に観測されたコーダと比較してみる。地盤の応答計算はSILVA (1976) にならい，Q 值を考慮した拡張された HASKELL マトリックス法を用いて行なう。しかし， SILVA (1976) が示したのは P-SV 問題に対するマトリックスのみなので, 同様に考えて SH 問題に対するマトリックスを構成して計算を行なつた。

Table 2. Structure of S-wave velocity, density and $Q$-value. $\mathrm{A}$ and $\mathrm{B}$ are the models whose $Q$ structures are lower and upper ones, respectively.

\begin{tabular}{|c|c|r|r|r|}
\hline $\mathrm{h}$ & $\rho$ & Vs & \multicolumn{2}{|c|}{$Q$} \\
\cline { 4 - 5 }$(\mathrm{m})$ & $\left(\mathrm{g} / \mathrm{cm}^{3}\right)$ & $(\mathrm{m} / \mathrm{s})$ & $A$ & \multicolumn{1}{|c|}{$B$} \\
\hline 10 & 1.5 & 170 & 10 & 20 \\
\hline 90 & 1.7 & 520 & 20 & 40 \\
\hline 00 & 1.7 & 600 & 20 & 40 \\
\hline 150 & 1.9 & 820 & 30 & 60 \\
\hline 380 & 1.9 & 1080 & 30 & 60 \\
\hline$\infty$ & 2.4 & 2400 & $\infty$ & $\infty$ \\
\hline
\end{tabular}

この様な計算をする際に問題になるこ とは，コーダは様々な入射角の後方散乱 $\mathrm{S}$ 波により構成されているので，特定の 入射角に対する応答だけでは計算できな いことである. しかし, Table 2 に示し た model A に対する SH 波の応答を計 算した結果，入射角は殆ど影響しないこ とがわかつた。たとえば，垂直入射にた いする入射角 $30^{\circ}$ の場合の増幅率の比 は, 平均約 0.95 であり, 入射角 $45^{\circ}$ の 場合は 0.9 , 入射角 $60^{\circ}$ の場合は 0.7 で ある、また，異なつた岩艋上ではコーダ 
の比とS 波の比が一致することは，大きい入射角をもつ波はコーダの形成に殆ど寄与してい ないことを示唆していると考えられる，従つて，入射角が大きくなると影響してくる SV 波 の効果を無視して応答を計算してもよいであろう．以上のことから，ここでは垂直入射の SH 波に対する応答を $\mathrm{S}$ コーダに対する平均的地盤の応答と考えて計算した.この様な単純化し た計算をしているので個々の位相の対応よりも RMS 振幅が，注淁一致すれば満足するもの とする。

\section{(2) 結 果}

計算に用いた地震は No. 12 の深発地震である. 計算に使われた構造を Table 2 に示す. この構造は, HORIKE (1985) と川部・他（1984）の結果を基に仮定したものである.また $Q$ 值については, 岸本 (1982) と YAMAMIZU et al. (1983) の結果を参考に, 適切と思われる 範囲の上下限值を Table 2 に示した， $Q$ 值の小さい方を model A, 大きい方を model B とし，その構造に対する応答を Fig. 11 に示す. これによると，2つのモデルとも S 波直接 波と考学られる S 波の立ち上がりの部分の約 2 秒間の RMS 振幅の大きさは, ほぼ再現で きている.このことは, 地下構造モデルは適切であることを示していると考えられる. しか し，コーダ部分に対しては, 計算された振幅が小さすぎて観測值が再現されていない。また, Table 2 に示した浅発地震の場合には, 観測されたコーダと計算されたコーダの振幅の差は更 に大きくなる．このことにより，地盤上でも岩盤上でもコーダが $\mathrm{S}$ 波の後方散乱波のみからな

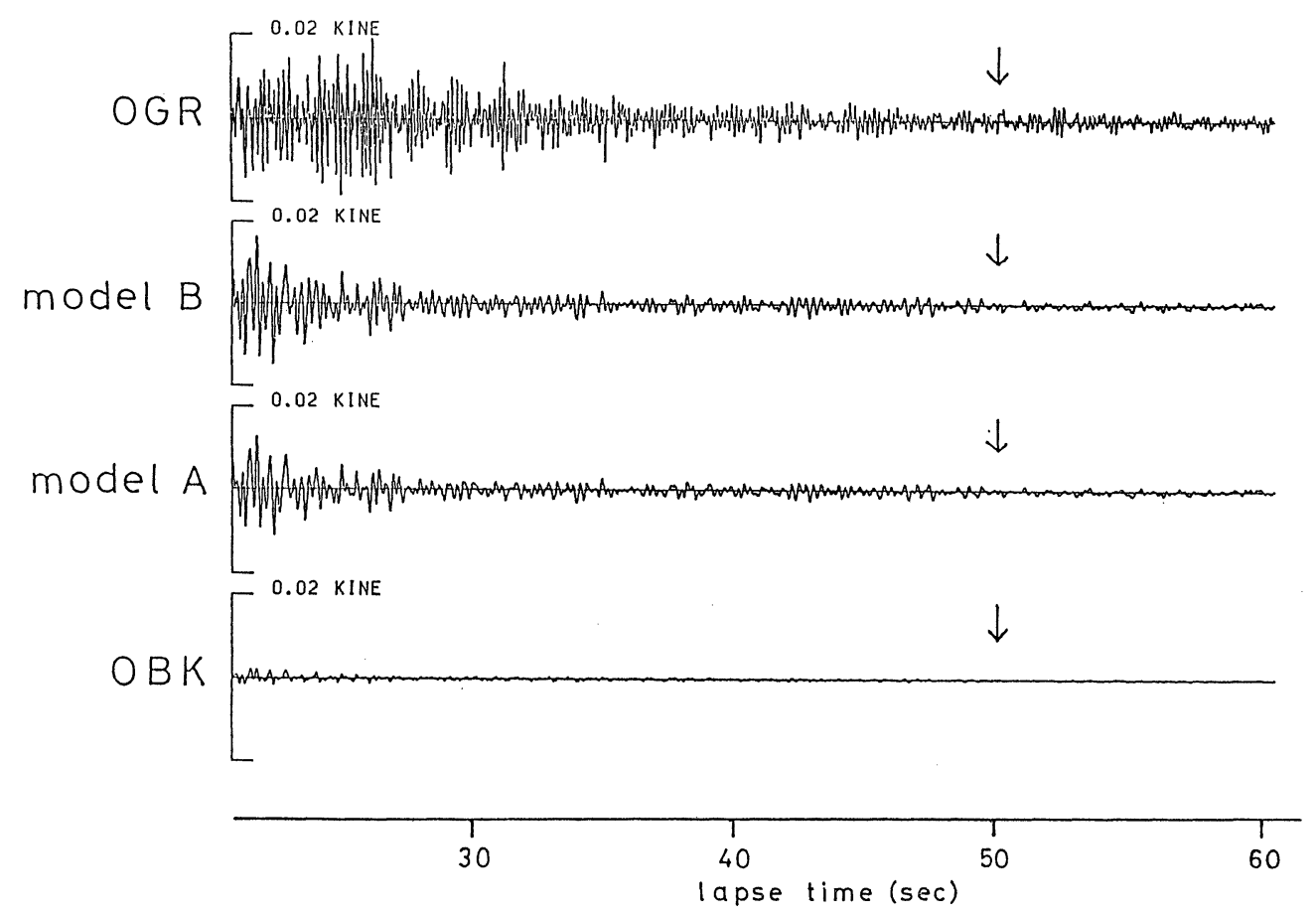

Fig. 11. SH responses caluculated by using the models A and B at OGR. The seismograms begin at the onset of S-wave. Arrows denote the time where coda amplitude ratios were estimated. 
り，地盤増幅度のみがその差異の原因であるという仮定は否定される，このようになる理由と して，地盤上に和けるコーダは表面波によつても構成されるためと考えられる．また，OGR においては，2７秒に大振幅の波が観測されている.この部分の原因は盆地構造による焦点 効果, 盆地堆積層による表面波の励起, あるいは, 堆積層の速度分布の摇らぎに起因している と考えられる. しかし，本稿の主題ではないので，別の機会に議論したい・

\section{§4. 議 論}

以上の解析結果から，地盤におけるコーダには S 波の後方散乱だけでなく，表面波が含まれ ている可能性が高いと考えられる. しかし, AKI (1981) の論文中において, SATo (personal communication) が関東平野の深さ $3 \mathrm{~km}$ の地中で観測されたコーダと地表で観測されたコー ダを比較した結果を報告しているが，それによると，関東地方においてはコーダに表面波が含 まれている可能性は否定されており，それと今回の結果とは一致しない，その理由としては， 両地域の構造の違いが考えられる. OGR は, Fig. 1 に示す様に盆地中央部にあるので, 二次 震源と考它られる盆地堆積層と周囲の古生層の山との境界から生じた表面波が集中しやすく， しかも二次震源から比較的近いため距離減衰も小さく, 二次的に生じた表面波がコーダの生成 に大きく寄与すると予想される. これに対して, 関東平野内の岩柣は, 二次的に生じた波が比 較的集中しにくい場所にあり，また，二次震源からの距離が比較的大きいため距離減衰も大き く, 表面波が観測されなかつたのではないかと考えられる. 以上のことから, 今回の解析結果 はすべての場合にあてはまるわけではなく, その観測点の地形的条件に応じて, 地盤上で観測 されるコーダの性質が大きく変化することを示しているものと思われる.

2 地点間のコーダの比を求める際に, 経過時間が何秒の所で比をとるべきかが問題になる. 3.1 でも述べたようにコーダの始まりを $\mathrm{S}$ 波の到着時間の 2 倍としたが，これは震源と観測点 を焦点とする棈円体上に散乱源を考光，それが近似的に球（長，短軸比が 0.86 以上）とみな せる.すなわち, 散乱源が観測点に対して等距離に分布しているとみなせるときをコーダの始 まりと考えて, 決定したのである.コーダを用いて $Q$ 值の推定をする際には, 対象としてい る散乱源の位置によつて, 解析に用いる経過時間は容易に決定できるが, 2 点間のコーダの比 を求める際には, 2 点間の距離も考慮に入れる必要がある.すなわち, 震源と観測点を焦点と する 2 組の楕円体が近似的に一致することが条件になる.よつて，2 地点間の距離に比べて震 源距離が長くない場合には，S 波の到着時間の 2 倍よりも，もつと後の時間で比をとる必要が ある.このような理由で, 今回の解析においては, 極近地地震についてもすべて, 同じ経過時 間 (50 秒) の所で比を求めた.

\section{$\S 5$. 結 論}

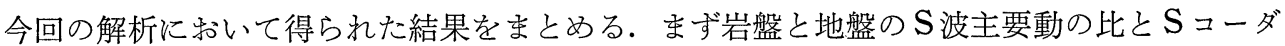
の比とを比較した結果, 岩盤間でのように S 波主要動とコーダとで比が一致せず, $3 \mathrm{~Hz}$ 以下 の周波数に拈いては，コーダの比がS 波の比よりも大きくなつた。また，コーダの方が比のば らつきが小さい岩盤上の場合と異なり、コーダの比も $\mathrm{S}$ 波の比と同程度のばらつきを示した。 ゆえに, コーダの比によつても，S 波主要動による場合よりも正確に地盤の増幅特性を推定す る事は出来なかつた。また，地盤における 3 点間のコーダの比を調べることにより， $1 \mathrm{~m}$ 程度 
の盛土の影響によつて, $6 \mathrm{~Hz}$ 以上の高周波が減衰することがわかつた．しかしそれ以外の場 所の各測定点間のコーダの比は 1 になり，場所による影響は小さかつたと思われる.

次に，三点観測の記録から推定された地盤でのコーダの位相速度は，同じ場所で別の方法で 推定されたレイリー波の位相速度と一致した。よつて，地盤に拈けるコーダには表面波が含ま れていると考兄られる. しかし，今回の解析に用いたトリパタイトの大きさや解析法のために， $5 \mathrm{~Hz}$ 以上の高周波及び速度の速い実体波については速度が求まらず，コーダに含まれる表面 波の割合を求めることが出来なかつた.

最後に, 既に別の研究で推定されている地盤の速度構造に対して計算された応答によつては, 地盤上で観測されたコーダを説明することはできなかつた。このことは，地盤に打けるコーダ が基盤から入射するS 波の後方散乱波のみでなく表面波の様に横方向から入射してくる波から も構成されている可能性を示すものであり，位相速度に拈将る結果を支持していると考兄られ る.

\section{謝 辞}

今回の研究にあたり, 終始指導をしていただいた京都大学理学部小林芳正助教授, 京都大学 防災研究所入倉孝次郎助教授に心から感謝の意を表します. 京都大学防災研究所院生の福山英 一氏には, 観測における助力など数多くの援助を得ました. 工学部建築学教室の篠崎祐三博士 には, 観測機器の便宜を計つていただきむした. また, 京都大学理学部地震予知観測地域セン ターには, 震源データを利用させていたただきました。また, 京都大学理学部院生の天池文男, 今住隆，阿部進氏には，有益な助言及び励ましをいただきました。ここに心から感謝いたしま 于.

観測においては，観測点を設置させていただいた北小倉小学校・北小倉保育所，観測場所と して巨椋池干拓地の利用を許可していただいた巨椋池土地改良区，また，作業の妨げになるに もかかわらず，今回の観測に協力していただいた巨椋池干拓地の農家の皆様には，本当に感謝 致します。

今回の解析には, 京都大学大型計算機センター FACOM M382 を利用した.

\section{文献}

AKI, K., 1957, Space and Time Spectra of Stationary Stochastic waves, with Special Reference to Microtremors, Bull. Earthq. Res. Inst., 35, 415-456.

AkI, K., 1969, Analysis of the Seismic Coda of Local Earthquakes as Scattered Waves, J. Geophys. Res., 74, 615-631.

AKI, K., 1981, Scattering and Attenuation of High-Frequency Body Waves $(1-25 \mathrm{~Hz})$ in the Lithosphere, Phys. Earth Planet. Inter., 26, 241-243.

AKI, K., 1981, Attenuation and Scattering of Short-Period Seismic Waves in the Lithosphere, in Identification of Seismic Sources-Earthquakes or Uunderground Explosion, E.S. Husebye and S. Mykkelveit, editors, D. Reider Publishing Co., Dordrecht, The Netherlands, 515-541.

Dziewonski, A., S. Bloch and M. Landisman, 1969, A Technique for the Analysis of Transient Seismic Signals, Bull. Seism. Soc. Amer., 59, 427-444.

Hasegava, A., N. Umino and A. Takagi, 1978, Double-Planed Deep Seismic Zone in the Northeastern Japan Arc, Tectnophysics, 47, 43-58.

HoRIKe, M., 1985, Inversion of Phase Velocity of Long-Period Microtremors to the S-Wave- 
Velocity Structure down to the Basement in Urbanized Areas, J. Phys. Earth, 33, 59-96. IRIKURA, K. and J. AKAmATSU, 1974, Earthquake Motions Observed on Rock and Ground, Bull. Disast. Prev. Res. Inst., Kyoto Univ., 24, 263-290.

IWATA, T. and K. IRIKURA, 1984, Estimation of Irregular Underground-Structure from Seismic Ground Motions, Bull. Disat. Prev. Res. Inst., Kyoto Univ., 34, 1-18.

Jenkins, G. H. and D. G. Watts, 1968, Spectral Analysis and Its Applications, San Francisco, Holden-Day, Inc.

川部喜朗・堀家正則・小林芳正・今住 隆，1984，簡単な観測システムによる CDP 浅層反射法の試 み, 物理探鉱, 37, 307-318.

岸本清行, 1982, 軟弱地盤に挑ける Love 波の減衰と $Q_{s}$ 構造の推定, 地震, 2, 35, 1-18.

狐崎長琅・後藤典俊・岩崎好規, 1971, 地震探査からみた京都盆地南部の地下構造とこれに関連した 地震工学上の若干の問題, 京都大学防苂研究所年報, 14A, 203-215.

Rautian, T.G. and V.I. Khalturin, 1978, The Use of Coda for Determination of the Earthquake Source Spectrum, Bull. Seism. Soc. Amer., 68, 923-943.

Silva, W., 1976, Body Waves in a Layered Anelastic Solid, Bull. Seism. Soc. Amer., 66, 1539-1554.

Singh, S. K. and R. B. HerrmanN, 1983, Regionation of Crustal Coda $Q$ in the Continental United States, J. Geophys. Res., 88, 527-538.

TsujIura, M., 1978, Spectral Analysis of the Coda Waves from Local Earthquakes, Bull. Earthq. Res. Inst., 53, 1-48.

Yamamizu, F., N. Goto, Y. OHTA and H. TAKAhashi, 1983, Attenuation of Shear Waves in Deep Soil Deposits as Revealed by Down-hole Measurements in the 2300 Meter-Borehole of the Shimohsa Observatory, Japan, J. Phys. Earth, 31, 139-157. 